\title{
Universal War Strategy Supported Political Integration Reviewed from The Third Sila Pancasila; The Unity of Indonesia
}

\author{
Agus Setyo Hartono \\ Universitas Pertahanan, Indonesia \\ Email: agusetyoh@gmail.com
}

\section{ARTICLE INFO \\ Date received : 01 April 2021 \\ Revision date : 04 March 2021 \\ Date received : 16 May 2021}

\section{Keywords:}

Strategy; universe war; political integration; unity

\section{ABSTRACT}

The understanding of uniting the nation's cultural diversity requires a strategy in handling it so that it does not become a breaker of Indonesian unity, in the political integration of diversity in party groups and their partisanship with government power, it becomes less and less pro to certain communities in society that are represented in dealing with various problems. Cultural diversity that characterizes the Indonesian nation is a nation's wealth or asset that must be preserved and it is hoped that it will lead to potential excellence in the world. Conflicts that are oriented towards division, disintegration of the nation, and want to liberate from the unitary republic of Indonesia require concrete efforts to be overcome for the sake of realizing national unity in the Universal War Strategy. Therefore, the researcher wants to examine how the implementation of a sense of unity and political integration as an element that plays a very important role in the universal war strategy, because the understanding of universal war in the face of non-military threats is needed from government agencies outside of defense, especially in the political dimension, so civic, universality and populist is a feature of the settlement with a universal war strategy.

\section{INTRODUCTION}

The dynamics of global and regional political developments are still colored by the struggle for influence and interest between the People's Republic of China (PRC) and the United States (U.S.) in several regions, especially in Asia (Mulyono, 2017). While in the perspective of national politics we are always tested by the political characteristics of the nation that is still in the pragmatic shackles of the elites as a consequence of multi-party democracy with the challenge of free speech among the people. Problems related to politics and unity arise in the form of differences in government policy between the central and regional, party riots, lack of issues that build national nationalism, banyknya conflict-prone areas, still growing radicalism, sepratism, dynastic politics, debates about Eka Sila and Trisila Pancasila, or perhaps the appearance of impressions on the medsos that seem to describe that Aceh is part of the Turkish state and along with the development of the times will always emerge new ideas in expression as a nation with risks and advantages as a country that diversity.

Hendropriyono in a talk show national dialogue from TV Tempo conveyed (global ideology; caliphate, maoism, racist liberalism, communism- clarification of the concept of pancasila to be free from ambiguity form the logic of identity, nationalism and national discipline (A.M Hedropriyono). Indonesia in today's development is always following the

\begin{tabular}{lll}
\hline How to cite: & Hartono, Agus Setyo. (2021) Universal War Strategy Supported Political Integration Reviewed \\
& from The Third Sila Pancasila; The Unity of Indonesia, 2(3). & \\
\hline https://doi.org/10.46799/jsss.v2i3.127 & \\
\hline E-ISSN: & $2721-5202$ & \\
\hline Published by: & Ridwan Institute
\end{tabular}


development of the global situation, especially related to the field of ideology that is increasingly the influence of the world with an understanding that continues to urgently influence the mindset of society. Globalization can be an opportunity and challenge for a country, one of which is Indonesia. Globalization also has a positive and negative impact for the nation and country (Kompas.com). The way of thinking colored by technological advances with the development of lifestyle is influenced by the rapid flow of information, the process of changing the culture and understanding that seems to be less sensitive to the importance of ideological context because it is less in discussion because new cultures form communication patterns that are replaced with machines or equipment. Horizontal conflicts triggered by the multiculturality of society, ethnic diversity, religion, race, class and social conditions still color the conflicts in the region (Pertahanan, 2015) (Ryamizard, 2015).

The national interest is the state's efforts to pursue power, where power is everything that can develop and maintain a country's control over another country (Morgenthau, 2017). In protecting the national interest of each nation will strive to exert its resource capabilities to support the realization of welfare and national security. Pancasila has the motto of Single Diversity Ika-an, with pluralism and multiculturalism that must be united by a "sense of togetherness" in the nationstate idiom following the spirit of nationalism that accompanies it (Mawardi, 2017) State ideology as a device of ideas or concepts of state thinking is as a value order that is expected to be actualized well by the state represented by the government and also by citizens. The ideology is basically a value that is mutually agreed to be used as a guideline in behaving and behaving as the identity of the state and all citizens (Silitonga, 2020). Pancasila is a spirit that gives life to the Indonesian nation in all respects, as a point of view, basis, or even as a foundation (Romadlon, 2016) In relation to the various laziness that occurs, the startegi of the universe war is associated with political integration and the "Indonesian Feeling", then there is a formulation of the problem that will be discussed in the form of "how the universe war strategy can be supported by the unity of the nation in the view of political integration" and "what is the most appropriate strategy in realizing unity in the implementation of political integration in the future". From the two things that are the problem, it is expected that the research carried out will be able to parse the most effective and efficient way out.

The purpose of the study was to get answers related to the laziness discussed to know "how the strategy of universal warfare can be supported by the unity of the nation in the view of political integration" and "what is the most appropriate strategy in realizing unity in the implementation of political integration in the future". By understanding both problems, it is expected that they will find a way out that can be used for academic and practical purposes in society.

The research conducted is expected to be able to provide benefits and academic contributions to various parties that carry out similar research, especially those that explore problems related to the field of universe war strategy with discussion and various theoretical foundations and can provide practical benefits related to society to provide usefulness in understanding the dynamics that occur.

\section{Strategy Theory}

The word strategy comes from the Greek "Strategos", when it appeared used during the 18th century. seen in a narrow sense as "The Arts of General". Or the 'art of setting' troops. B. H. Liddell Hart's defines that strategy is The art of distributing and applying military means to fulfill the ends of policy (Hart, n.d.) With this understanding, the view of strategy in the sphere of political integration and unity of Indonesia is a resource that influences the achievement of goals because the methods or ways used in achieving goals will follow the dynamics that occur in the small potential of resources owned. Leaders in any line will need all the tools at their disposal so that at the time of use or operation will follow the development of challenges or threats supported by the ability to carry out a strategy in achieving goals. 


\section{The Theory of Universe War}

Universal war is a war (not just a war) whose implementation involves all national citizens, territories and resources aimed at upholding the sovereignty of the country, the integrity of the territory, and the safety of all nations from all threats (Johannes Suryo Prabowo, Putranto, \& Heri Budianto, Didik Haryadi Santoso, Agung Prabowo, Fajar Junaedi, Setio Budi H. Hutomo, Edwi Arief Sosiawan, 2016).

In understanding the universe war is very related to the unity of the nation because in view of regional and populist diversity is influenced by political integration as a means to glue the unity of the nation. As a strategy of defense of the state of universal war in regional understanding is a comprehensive startegi in the unity state of the Republic of Indonesia while associated with unity and political integration, the view of unity and unity of the nation should be reflected in the implications of democracy that can be used as a source of strength, especially the support of the quality of human resources that are united to support the national interest.

\section{Theory of Political Integration}

Lion Lindberg in Political Integration as a Multi dimensional Phenomenon requiring Multivariate Measurement, Autumn edition of the International Organization Journal, 1970 (Lindberg, 1970) argues that thinking "political integration is a process by which nations no longer desire and are able to organize domestic and foreign political keys independently of others, instead seeking joint decisions or delegating the policy-making process to new control organs (Alfred, 2012). With the view of political integration, the process of policy making in the new organ control, by looking at the fact of dynamism in democracy, there is a need for unity of views in politics with the bestiality becomes a decisive factor because the need to control the sectoral ego that has the potential to use politics for the benefit of pragmatic groups.

\section{Unity Theory}

According to Notonegoro (Kaelan, 2002) The principles of Indonesian Nationalism (Persatuan Indonesia) are composed in a single compound unity, namely: 1 . Historical unity, namely the
Indonesian nation that grows and develops in a historical process, since prehistoric times, Srivijaya, Majapahit, Youth Oath october 28, 1928 and until the Proclamation of 1945 and then formed the state of the Republic of Indonesia. 2. Unity of fate, which is in the same historical process and suffered the same fate that is in the suffering of colonization and happiness together. 3. Cultural unity, namely cultural diversity grows into a form of national culture. 4 . The unity of the territory, namely the existence of the Indonesian nation can not be separated from the spilled blood of Indonesia. 5. The unity of the basic spirituality, namely the existence of ideas, ideals and values of spirituality that is entirely knotted in Pancasila. In the opening of the NRI Constitution of 1945 paragraph II mentioned an independent, sovereign, just and prosperous country. What is meant by a united Indonesia is a united state. So the unity and unity of the nation is a joint state. The state of Indonesia is not a country divided in the phrases "The state protects all Indonesians" and "all indonesian bloodshed". Such a goal means that the state of Indonesia, the Nation of Indonesia and the territory of the indonesian homeland is a unity (Hanafi, 2018). With this understanding, unity is the basic capital in the running of a strategy so that in political integration also requires the orintasi of unity-based thinking for all people and the need for a positive way of view in the implementation of democracy in order to provide a sense of calm and peace in politics, as stated in the third precept of "Indonesian unity" in Pancasila.

\section{METHOD}

In this study using narrative method, descriptive, by collecting data through interviews, library studies, field notes, personal documents, and official documents presented systematically to describe the relaitas that occurred.

\section{RESULTS AND DISCUSSION}

\section{Understanding the implentation of the third "Persatuan Indonesia" in political integration.}

Views on politics; According to prof. Ramelan Surbakti, in his book Understanding Political Science, (Ramlan, 1992) there are 
five political views; A.. Classical understanding with the main character Plato Greece, politics is interpreted as an effort to make common virtue, meaning to realize welfare / justice so that the manager of the country should have a commitment in welfare. b. Institutional understanding, relating to the maintenance of the state and government how the state treats its citizens and how citizens are committed to their country, how the regime performs against its country. c. Understanding Power, identic politics with the power of a political scientist Harold Laswel with "Who gets What, when and how", who gets what, when and how, What is meant is anyone who gets power is people who enter politics, when or when related to the time limit in managing power and how or how to get power done by election or at a time when the kingdom is done with a hereditary system or even some who went through a coup d'etat in applying his power. d. Understanding Functionalism, politics is all activities related to the formulation and implementation of policies. System theory explains how the policy process is explained from input-processoutput. e. Understanding Conflict or opposition, politics will not be separated from the opposition Karl Max conveys to every system in politics will always rub. Interagency conflicts are inevitable until now.

From the opinion of politics above, in democracy of course there will be a dynamic because of the understanding of power that tends to be on behalf of the people, policy making or regulation will provide space for the most important group that tends to use it as a means of fulfilling the interests of the group, this has happened a lot because basically power will push towards the oligarchs for the sake of the continuity of power itself. In the view of the unity principle, The Indonesian Nationality reflects a unity in diversity and novelty in error. In phrase (Geertz, 1963) Indonesia is like old wine in a new bottle, aka the cluster of old people in a new country (Latif, 2020) The view reveals as if there is a long-tended understanding in the new organizational corridors so that in the view of unity we instead get positive conditions but that need to be anticipated to the importance of changes in the way of thinking and acting is associated with the dynamics that occur in the strategic environment both global and regional and various things that are happening in the country.

\section{Political integration and national integration in Indonesia}

Something not strange actually when a country has a revolt and tinged with civil war. Whether it is in the safest country in the world even though the issues have blown away due to conflict at certain levels. Identity Politics in Indonesia, as quoted from Ma'arif in his book Identity Politics and the Future of Indonesian Pluralism", explains that especially in Indonesia, Identity politics is more related to ethnicity, religion, ideology and local interests represented generally by political elites with their own articulation. (Maarif, Maarif, Ali-Fauzi, \& Panggabean, 2010) (Ilyas, 2020) Basically political conflicts always color the running of democracy in Indonesia and various problems arise as a picture of how vulnerable people are to incitement so that sometimes confuses the understanding of the truth of information. The opinions of James J. Coleman and Carl G. Rosberg see that political integration is part of national integration. In this case, national integration has two dimensions, namely vertical and horizontal dimension. Vertically, national integration aims to bridge the gap of difference that may exist between elites and the masses in order to develop a unified political process and participating political societies. Then horizontally national integration aims to reduce the discontinuity and tension of regional culture in order to create a homogeneous political society (Coleman \& Rosberg, 1964).

Integration comes from the English "integration" which means perfection or whole. National integration is the effort and process of uniting differences that exist in a country so as to create harmony and harmony nationally. As we know, Indonesia is a very large nation both from its culture and region (Astawa, 2017).

With the diversity of political culture that still has a tendency to be easily divided due to the emergence of an understanding of power that is growing and growing. The development of the situation and the condition of the political environment with the impartiality to power causes unhealthy competition and uses all means to be as close 
to power as possible, this is very disruptive to the unity of the nation and will interfere in the application of the strategy of universal war because regionally at least politics will be influenced by the binding behavior of the party that is the parent. In view of the universality and populism, the conflict that occurs in politics will disturb the understanding of the public to make political vehicles as a means of fighting for its interests.

\section{The Universal Defense Strategy is associated with political integration}

(Indonesia, 2021) In the discussion of policy implementation of nonmilitary defense directed in the face of the threat dimension of the political field consisting of the type of threat of disintegration of the nation, euphoria and anarchic democracy, mobilization / gathering of masssa forces and separatism is at the authority of the Ministry of Home Affairs as the main element supported by the Ministry of Foreign Affairs, Ministry of Foreign Affairs, Kemenkumham, Kemendikbud, Kemensos, Kemenkominfo, Attorney General, TNI / Polri, Local Government and related institutions. James J. Coleman and Carl G. Rosberg, seeing political integration as part of national integration, in their view national integration has two dimensions, namely vertical (or elitemass) and horizontal (or territorial) dimensions. In the vertical dimension of society in certain elites have a way of looking at the tendency to maintain their positions and interests to further strengthen their power, but in terms of policies given to the community will always consider the interests of the group. (Coleman \& Rosberg, 1964)

Regional strategy, political system should still be directed to maintain and maintain Pancasila as the basis of philosophy of all Indonesians in the life of society, nation and state, and be used as the basis of struggle (J. S. Prabowo, 2019) In the view of the unity principle associated with political integration refers to the mandate of Jakum Hanneg 2020-2024 by involving ministries and institutions outside the ministry of defense with a pattern of regional development synergistic to address problems related to political conflicts. In view of regional problems with politicaldimensi can be given efforts in stages from the center to the region in accordance with the level of authority applicatively solve problems in their respective groups, if the problem in the region that has a tendency to disintegrate the nation then local government officials in cooperation with the TNI / Police officers in the region so that it can be resolved properly if experiencing obstacles then can coordinate in stages at the level above. Basically solving problems related to Indonesian unity in political integration is a nonmilitary threat so that regionally re-adhesive in the frame of unity is a shared responsibility so that the democratic atmosphere remains within the frame of Pancasila, especially the third syllabus of "Persatuan Indonesian".

The strategy of persimmon, persimmon is realized through the deployment of all indonesian national strengths and resources to be mobilized in the interests of facing the form of threats, both from outside and from within the country (Johannes Suryo Prabowo et al., 2016) With the increasing conflict between groups, the deployment of national resources is needed as a focus in supporting the improvement of defense capabilities. In the face of domestic threats in the form of political integration that has the potential to disrupt the unity of the nation, it is necessary to manage resources so that it is not contested by certain groups to meet the interests of their groups but instead strives to be willing to manage it into a force that is ready to be mobilized to support the national interest.

Populist strategy, populism is realized through the participation of all Indonesians in accordance with their roles, abilities, professions, and expertise as a manifestation of the rights and obligations of every citizen in the defense of the country (Johannes Suryo Prabowo et al., 2016) Various ways to overcome conflict or war can be done by the ability of human resources or people as a form of parsitipasinya in fighting the enemy of the state. In the political dimension the problem of political integration requires the role of society in certain groups with its position to immediately try to solve the problems that occur. Indonesian unity as a precept that hints at the importance of the role of unity in overcoming the threat to national unity, so that it takes awareness of the defense of the country for every human being to be willing to abandon the sectoral 
ego of his group in order to build strength to protect the national interest.

\section{CONCLUSION}

From the description above, it can be concluded that the strategy of universal war can be supported by the condition of national unity with positive political integration oriented to the national interest and the most appropriate use of strategy in realizing unity in the implementation of political integration in the future.

From the conclusions and descriptions above can be recommended the need for consistency from ministries or institutions outside the ministry of defense to carry out its function as a leading sector in its dimensional responsibilities in accordance with the mandate of presidential decree No. 8 of 2021 on Jakumhanneg. Related to the integration of politics and unity of the interior ministry and other ministries and institutions can move to address the problem according to their respective levels and fields.

\section{REFERENCES}

Alfred, H. S. (2012). Pengertian Pembangunan Politik.

Astawa, Dr I. Putu Ari. (2017). Demokrasi Indonesia. Universitas Udayan. Google Scholar

Coleman, James S., \& Rosberg, Carl G. (1964). Political parties and national integration in tropical Africa. University of California Press. Google Scholar

Geertz, Clifford. (1963). The integrative revolution: primordial sentiments and civil politics in the new states. Old Societies and New States: The Quest for Modernity in Asia and Africa, 105-157. Google Scholar

Hanafi, Hanafi. (2018). Hakekat Nilai Persatuan Dalam Konteks Indonesia (Sebuah Tinjauan Kontekstual Positif Sila Ketiga Pancasila). Jurnal IImiah Pendidikan Pancasila Dan Kewarganegaraan, 3(1), 56-63. Google
Scholar

Hart, Basil Liddell. (n.d.). BH Liddell Hart. Google Scholar

Ilyas, Ilyas. (2020). Islam dan Kebangsaan: Pergumulan dalam BPUPKI, PPKI, dan Piagam Jakarta. Buletin Al-Turas, 26(1), 19-35. Google Scholar

Indonesia, Presiden republik. Peraturan Presiden nomor 8 tahun 2021 kebijakan umum pertahanan negara tahun 2020 2024. , (2021). Google

Kaelan, M. S. (2002). Filsafat Pancasila Pandangan Hidup Bangsa Indonesia. Yogyakarta, PARADIGMA Yogyakarta. Google

Latif, Yudi. (2020). Wawasan Pancasila. Bandung. Google Scholar

Lindberg, Leon N. (1970). Political integration as a multidimensional phenomenon requiring multivariate measurement. International Organization, 24(4), 649731. Google Scholar

Maarif, Ahmad Syafii, Maarif, Ahmad Syafii, Ali-Fauzi, Ihsan, \& Panggabean, Syamsu Rizal. (2010). Politik identitas dan masa depan pluralisme kita. Pusat Studi Agama dan Demokrasi (PUSAD), Yayasan Wakaf Paramadina. Google scholar

Mawardi, Imam. (2017). Pancasila sebagai landasan karakter pemimpin menuju perubahan ideal. Jurnal Pendidikan Pancasila Kewarganegaraan Dan Hukum, 1(1), 39-48. Google Scholar

Morgenthau, Hans J. (2017). Positivism, functionalism, and international law. In The Nature of International Law (pp. 159-184). Routledge. Google Scholar

Mulyono, Hari. (2017). Geostrategi Indonesia dalam Dinamika Politik Global dan Regional. Jurnal Kajian Lemhannas RI, 5(1), 19-30. Google Scholar

Pertahanan, Kementerian. (2015). Buku putih pertahanan Indonesia. Jakarta: 
Kementerian Pertahanan Republik Indonesia. Google Scholar

Prabowo, J. S. (2019). Pokok-Pokok Pemikiran Strategis Tentang Perang Semesta. Jakarta. Google

Prabowo, Johannes Suryo, Putranto, Joko, \& Heri Budianto, Didik Haryadi Santoso, Agung Prabowo, Fajar Junaedi, Setio Budi $\mathrm{H}$. Hutomo, Edwi Arief Sosiawan, Iswandi Syahputra. (2016). Perang semesta dalam kajian budaya dan media (1st ed.). Bandung. Google Onesearch

Ramlan, Surbakti. (1992). Memahami ilmu politik. Grasindo. Google Book
Romadlon, Suryo Gilang. (2016). Implikasi Pergeseran Sistem Politik terhadap Hukum dan Birokrasi di Indonesia. Jurnal Konstitusi, 13(4), 868-885. Google Scholar

Silitonga, Tatar Bonar. (2020). Tantangan globalisasi, peran negara, dan implikasinya terhadap aktualisasi nilainilai ideologi negara. Jurnal Civics: Media Kajian Kewarganegaraan, 171), 15-28. Google Scholar

\section{Copyright holder: \\ Agus Setyo Hartono (2021)}

First publication right:

Journal of Social Science (JSS)

This article is licensed under:

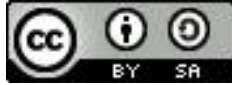

